\title{
CAPITOLO I
}

\section{Introduzione}

\section{Stefano Costa ${ }^{* *}$, Giovanni Luca Annibale Pesce ${ }^{* *}$}

Quando nel pomeriggio dell'8 maggio 2006, a conclusione della prima edizione del workshop, proponemmo di ripetere la fruttuosa esperienza appena conclusa a Grosseto, vi fu certamente una dose di fiducia inaspettata nei confronti di un gruppo giovane e non strutturato come era (e in gran parte è tuttora) IOSA. D'altra parte, in mancanza di altre proposte analoghe, rimandare a un futuro indefinito la prosecuzione delle molte interessanti discussioni avviate in quella giornata sembrava una occasione sprecata.

IOSA è un working group che è spesso stato chiamato progetto, avviato nel 2004 in seno al grupporicerche, con l'obiettivo di valutare la applicabilità del software libero nella pratica archeologica. L'attività di IOSA ha attraversato varie fasi, dalla sistematica raccolta e catalogazione di software sul sito web http://www.iosa.it/ fino allo sviluppo di software dedicato, documentazione avanzata e al coinvolgimento in iniziative di respiro internazionale. Nel 2007 IOSA era in un momento di passaggio da una prima fase "esplorativa" ad una più propriamente applicativa, anche grazie alle opportunità offerte dai rispettivi ambiti di studio, con le prime timide sperimentazioni nella programmazione in linguaggi di alto livello (Python), gestione di sistemi informativi in rete e catalogazione di beni culturali.

Prima del workshop di Grosseto, come gruppo facente capo all'Istituto Internazionale di Studi Liguri (IISL) avevamo ottenuto la disponibilità da parte della sezione di Genova (di cui allora era presidente il prof. Tiziano Mannoni) a ospitare una seconda edizione dell'incontro. L'importanza di una successione aperta e pubblica si è rivelata un fattore chiave anche negli anni successivi per la buona riuscita del workshop.

L'organizzazione ha significato anzitutto un impegno in termini umani, ancora prima che economici, a tutti i livelli. Nel grupporicerche Alessia Mantovan, Francesco Bertazzo e Luca Bianconi hanno curato la segreteria orga- 
nizzativa, con il supporto di Matteo Sicios. Da quell'occasione Luca Bianconi è poi entrato stabilmente in IOSA, a testimonianza di quanto questo incontro sia stato importante non solo per il movimento del software libero in archeologia ma anche per la crescita numerica e intellettuale del nostro piccolo gruppo. Regione Liguria ha erogato un finanziamento che ci ha consentito di coprire interamente i costi relativi alla pubblicazione. La Ipsilon s.c.r.l. ha sponsorizzato il workshop, in particolare il pranzo offerto ai relatori. Il Museo di Sant'Agostino di Genova, parte dei Musei Civici Genovesi, ha messo a disposizione i suoi locali nella prestigiosa sede di piazza Sarzano, in una anteprima di quello che sarebbe divenuto un rapporto fisso tra IISL e Museo negli anni successivi. L'Istituto per la Storia della Cultura Materiale (ISCUM), oltre a garantire il suo patrocinio all'incontro, ha mostrato nell'introduzione di Severino Fossati come gli approcci quantitativi in archeologia abbiano una lunga - e spesso dimenticata - tradizione a Genova, anche al di fuori delle sedi universitarie. Per molti anni l'ISCUM ha rappresentato per IOSA un punto di riferimento nella combinazione di approcci e metodologie alla ricerca tout court, non ultimo per il carattere sostanzialmente pratico ("ligure" si potrebbe dire) riscontrabile anche nelle digressioni più teoriche. L'IISL ha garantito la possibilità di rapportarci formalmente con altre istituzioni a tutti i livelli, sostenendo questa e altre iniziative portate avanti da IOSA.

Una persona più di tutte le altre ci ha ispirato a lavorare con dedizione e umiltà (non sempre ci siamo riusciti appieno) per il puro, semplice e cocciutamente infantile piacere della ricerca, ed è stato il professor Tiziano Mannoni. In apertura di questo incontro, abbiamo avuto la fortuna di ascoltare la sua introduzione, una delle rare occasioni in cui Mannoni si è confrontato in pubblico con il mondo dell'informatica applicata all'archeologia.

Con questa pubblicazione si salda il debito nei confronti della comunità che negli anni è cresciuta intorno al workshop, e nei confronti degli autori che hanno visto ritardata troppo a lungo la disponibilità del proprio lavoro.

Abbiamo operato una scelta inusuale per la pubblicazione di questo volume, tuttavia in linea con i principi della condivisione e della disseminazione. Ubiquity Press si è dimostrata in grado di soddisfare tali esigenze in modo eccellente, e ci sembra utile un approccio anche in questo caso pionieristico, rivolgendoci all'estero per ottenere un prodotto editioriale digitale che in Italia ancora scarseggia, mentre rimane forte il solco della tradizionale pubblicazione cartacea e l'uso preponderante del PDF come unico formato digitale. Il tempo dirà se abbiamo avuto ragione.

Il lasso di tempo che ci separa ormai dal 2007 consente di dedicare uno sguardo distaccato e analitico ai lavori presentati, con una valutazione mirata anzitutto alla sostenibilità delle scelte tecnologiche allora adottate. Il workshop non ha mai adottato toni enfatici nei confronti di alcuna tecnologia né tantomeno sul software libero e open source, ma è indubbio che talvolta prevalgano scelte dettate da fattori esterni (in base alla "buzzword" più in voga in un determinato momento) e che tali fattori esterni mutino senza alcun controllo 
da parte nostra. Varrà quindi la pena di adottare uno sguardo pragmatico all'informatica, non tanto centrato su astratte tipologie di software o sistemi (uno per tutti: GIS), quanto sull'ecosistema che genera e consuma il software. È indubbio che il software libero, per come si è evoluto negli ultimi 15 anni, presenti un vantaggio schiacciante rispetto al software proprietario, grazie alla possibilità di seguire nei minimi dettagli il suo sviluppo, le problematiche tecniche che ne possono rendere difficoltosa l'adozione e la crescita, fino alla precoce diagnosi di una eventuale stagnazione del progetto (un fenomeno molto diffuso, contrariamente a quanto si può credere). I repository, le mailing list, i bug tracker sono impietosi testimoni dello stato di salute di un progetto, ma al tempo stesso sono lo strumento tramite il quale possiamo direttamente influenzare il progetto stesso. Questo volume è altrettanto impietoso, e comprende progetti di sviluppo software completamente abbandonati, sperimentazioni basate su applicazioni ormai del tutto obsolete, con la dimostrazione di scelte non attente o semplicemente sfortunate. Tale situazione deve essere oggetto di seria riflessione per chi ha partecipato ai workshop e per chi si accinge alla lettura di questo volume, anche alla luce di una promessa largamente mancata: la disponibilità del codice sorgente dei programmi presentati, con una licenza libera. Su questo specifico problema abbiamo più volte espresso il nostro disappunto, in particolare a partire dal 2009 quando IOSA ha intrapreso lo sviluppo di diverse applicazioni, tutte sempre disponibili dal primo momento in rete, con una licenza libera, in pieno accordo con la filosofia "release early, release often" che ha fatto la fortuna di molti software liberi. Troppo spesso vengono invece addotte banali giustificazioni ("ci sono alcune cose che prima vanno sistemate"), tanto più intollerabili se si pensa che generalmente riguardano software per la gestione di dati archeologici, sulla cui integrità e sostenibilità è necessario un controllo collettivo ben più intenso di quanto sia ad oggi praticato.

Di alcune scelte effettuate tra 2006 e 2007 siamo ancora oggi particolarmente orgogliosi. La più importante è certamente l'introduzione della condivisione dei dati archeologici come tematica centrale, affiancata al software libero. Questa tematica nasce da una intuizione di Giancarlo Macchi Jánica, a cui abbiamo avuto la fortuna di poter associare un esperto di ambito internazionale come Andrea Glorioso, facente capo a Creative Commons Italia. L'esperienza positiva è continuata nel 2008 ed è ora divenuta argomento centrale di incontri e gruppi di lavoro internazionali, sotto il nuovo nome di "open data", che non era ancora stato coniato. La comunità di questo workshop può vantarsi di essere tra i precursori del movimento open data in Italia, ma a poco servirebbe tale vanto senza una applicazione concreta ed estensiva degli spunti e dei cambiamenti che questo movimento propone. L'impegno di IOSA in questo senso non si è limitato al workshop e ha condotto nel 2009 all'organizzazione di un seminario tematico su "Diritti d'autore e banche dati per i beni culturali" ${ }^{1}$ in cui le possibilità, le sfide e i problemi posti dalla condivisione in rete delle banche dati archeologiche, e dei beni culturali in generale, sono stati 
affrontati da diversi punti di vista, incluso quello degli archeologi professionisti, troppo spesso e troppo regolarmente lasciati fuori dal dibattito accademico. Da questo punto di vista, è stata particolarmente significativa la partecipazione di Francesco Uliano Scelza dell'Associazione Nazionale Archeologi, in sostituzione del presidente Tsao T. Cevoli, il cui contribuito è pubblicato nel presente volume. La partecipazione delle associazioni professionali è diventata una costante del workshop negli anni successivi, costituendo anche una occasione di rivendicazione per tutti quei professionisti che si vedono privati di un riconoscimento intellettuale per il proprio lavoro, o dei permessi per lo studio di reperti custoditi nei magazzini delle soprintendenze. L'approccio di IOSA è sempre stato di grande apertura nei confronti di queste rivendicazioni, a patto che esse non costituiscano un motivo per la ulteriore "chiusura" delle informazioni archeologiche.

Nel 2007 costituì una novità assoluta anche la partecipazione di un tecnico della Soprintendenza per i Beni Archeologici della Liguria, Andrea Crosetti, il cui contributo non è purtroppo incluso nella presente pubblicazione. Nel 2012, con l'organizzazione della settima edizione del workshop da parte della Soprintendenza Speciale per i Beni Archeologici di Roma, il cerchio si è chiuso e da "stranezza" la presenza delle istituzioni pubbliche preposte alla tutela è diventata un cardine, tanto più importante se si pensa che questo avviene in un periodo di profonde trasformazioni per l'intera Pubblica Amministrazione, inclusa la digitalizzazione dell'intero procedimento amministrativo, e le importanti novità introdotte dal Codice dell'Amministrazione Digitale in tema di adozione del software libero e libertà di riutilizzo delle banche dati pubbliche.

L'edizione 2007 del workshop è ad oggi l'unica organizzata da una istituzione non universitaria o di ricerca (l'Istituto Internazionale di Studi Liguri è una ONLUS, attiva nella tutela del patrimonio culturale), e insieme a quella del 2008 l'unica organizzata da personale non strutturato (nel 2007 Giovanni Pesce era libero professionista e Stefano Costa studente all'Università di Siena). Sebbene non possa costituire una giustificazione, questa "eccezione" può forse spiegare il ritardo nella pubblicazione, ma anche la grande libertà che abbiamo potuto esercitare nelle scelte di merito e di metodo, senza alcuna costrizione esterna.

Durante questa seconda edizione del workshop, alle relazioni degli autori qui presentate fece seguito un approfondito dibattito, mirato in modo particolare alla condivisione dei dati archeologici a cui si è fatto riferimento sopra. Di questo dibattito abbiamo conservato una registrazione video, che intendiamo mettere a disposizione del pubblico come è stato già fatto per il workshop 2009. I filmati saranno disponibili tramite il sito archeofoss.org.

L'impegno di IOSA nei confronti di ArcheoFOSS continua, con la periodica organizzazione di incontri tematici, la redazione del sito web unificato sul dominio archeofoss.org e la promozione del workshop a livello nazionale e internazionale. 
On 8th May 2006, at the end of the first workshop in Grosseto, we proposed to repeat the meeting on the next year in Genoa. We could not expect such a good response from the participants, particularly given that IOSA was - and still is - an unstructured group of students and researchers. However, everybody agreed that it would have been a missed opportunity not to follow up on the interesting discussions we had only started on that day.

IOSA is a working group that has been often called a project, started in 2004 within grupporicerche, with the aim of evaluating if and how free and open source software could be used in everyday archaeological practice. The activity of IOSA has been going through several phases, from the initial cataloguing of software programs on the http://www.iosa.it/ website, to the development of dedicated software tools, advanced documentation and the involvement in international initiatives. In 2007 IOSA was in a moment of passage between the first "explorative" phase and the following phase, with the first applications in our respective fields of studies, some experiments in programming with highlevel languages (Python), the management of web-based information systems and the never ending cataloguing of cultural heritage.

Before the workshop in Grosseto, as a group within the Istituto Internazionale di Studi Liguri (IISL) we had already been given a preliminary approval from the local committee in Genoa (directed by prof. Tiziano Mannoni at that time) for hosting the second workshop. Having an open and public discussion about where the next meeting should take place has always been very important for the organisation and participation of the wider community.

Organising this workshop required a significant effort, not only in quantifiable costs but also in time and patience, at all levels. For the grupporicerche we had substantial support by Alessia Mantovan, Francesco Bertazzo and Luca Bianconi, with the general supervision of Matteo Sicios. Since then, Luca Bianconi has become a member of IOSA, a glimpse of how important this workshop has been, not only for the free software movement in archaeology, but also for the development of our small group. Regione Liguria generously covered the costs of this publication. Ipsilon s.c.r.l. sponsored the workshop, particularly the coffee- and lunch-break for the speakers. The Museo di Sant'Agostino in Genoa, part of the Musei Civici Genovesi network, let us use their meeting hall in the beautiful medieval building in piazza Sarzano, in an anticipation of the long-standing relationship the IISL now has with the museum. The Istituto per la Storia della Cultura Materiale (ISCUM) not only gave their support to our initiative, but explained during the introductory talk by Severino Fossati that quantitative approaches in archaeology have a long - and too often forgotten - tradition in Genoa, even outside the university. For many years the ISCUM has represented for IOSA a reference to look at, in their combination of approaches and methods to research. We found equal inspiration in the very practical nature of their work ("Ligurian" we might say), even when dealing with highly 
theoretical topics. The IISL made it possible for us to have a formal relation to other organisations and public bodies at all levels, giving substantial support to this initiative as they did with many others.

There was one person above all others who inspired us to work with perseverance and modesty (we haven't always succeeded in that), for the simple, stubborn and childish pleasure of research: prof. Tiziano Mannoni. At the beginning of this workshop, we all had a unique opportunity to listen Mannoni dealing with archaeological computing.

With this publication we settle our debt to the wide community that has grown around the workshop in the past years, and to the authors who have been waiting far too long to see their work published.

We made an unusual choice for the publishing of this volume, but we believe that this choice is consistent with the principles of sharing and dissemination. Ubiquity Press was able to provide us with an excellent work, and we deemed useful to look abroad for a digital publishing product that is still lacking in Italy, where instead traditional publishing is still very strong and PDF is almost the only digital format. Time will tell if we were right with this choice.

The long delay between this publication and 2007 - when the workshop took place - gives us a good opportunity to make assessments on the works presented, particularly from the point of view of sustainability. The workshop never promoted "blind faith" in any technology, including free and open source software, but it is no doubt that in some cases the choice of one specific technology may be based on external factors (with "fashionable" and "hype" at the lower end of the spectrum), that fall largely out of our control. It is necessary to adopt a critical approach to information technology, one that is not focused on abstract categories of software or systems (one above all: GIS), but rather on the "ecosystem" that generates and uses software. In practice, free and open source software has one significant advantage over proprietary software: the possibility to follow its development in every detail, to understand the problems that may block its growth, to notice stagnation at a very early stage (as such, a phenomenon that is much more widespread than usually believed). Software repositories, mailing lists, bug trackers are merciless witnesses of the "health status" of a project. At the same time, they are the way for us to engage with it. This volume is merciless as well, and includes software projects that were completely abandoned, experiments based on now obsolete programs, showing unlucky or careless choices. Such situation should be a serious concern for those of us who took part in the workshop and the readers of this volume, particularly when considering one major issue: the availability of source code for the programs that were presented, under an open license. IOSA has already explained our disappointment at this situation, particularly since 2009 when we started developing applications ourselves. All those applications have been available since day 0 , under an open license, following the "release early, release often" philosophy behind many successful software projects. But we see too often trite excuses ("it is not ready yet") instead of source code, and that is unacceptable 
because in most cases the applications under discussion are for the management of archaeological data. It is clear that the sustainability and fitness of such applications needs more collective control and assessment.

We are proud of some of the choices we made in 2006 and 2007 when organising this workshop. The most significant of these choices is almost certainly introducing the sharing of archaeological data as a key topic alongside free and open source software. This topic was initially an idea from Giancarlo Macchi Jánica, and we had a great opportunity to discuss it in 2007 with Andrea Glorioso, at that time already an international expert, member of the Creative Commons initiative. This positive approach has been continued in 2008 and it is now a central topic for international meetings and working groups, under the new name of "open data", that was not yet existing back then. The community of this workshop can be proud too, being one of the first pioneers of the open data movement in Italy, but such pride would be of little use without any practical developments. For this reason, in 2009 IOSA organised a seminar on "Copyright and databases in Cultural Heritage" ${ }^{2}$, where all the challenges and problems resulting from sharing cultural heritage databases (largely from a theoretical point of view) were discussed from several different points of view. These points of view included professional archaeologists, who are too often disregarded and left out of any debate on archaeological practice. From this point of view, it was very important for us to have already in 2007 a representative from the Associazione Nazionale Archeologi (ANA), Francesco Uliano Scelza. Tsao T. Cevoli, the organisation president, could not attend the workshop but his paper was included in this volume. The participation of professional organisations has become a regular feature in the next years of the workshop, and it represents an opportunity for demanding a better intellectual reward for their work and skills, such as allowing access to finds under State custody for study purposes. IOSA has always supported these demands, as long as they are a means to a wider sharing of information.

There was another significant "surprise" in this workshop, namely the participation of staff from the local Soprintendenza per i Beni Archeologici della Liguria, Andrea Crosetti, whose paper could unfortunately not be included in this volume. In 2012, with the Soprintendenza Speciale per i Beni Archeologici di Roma organising the 7th workshop, the circle is full and the Soprintendenze have become a key component of the workshop. The importance of their engagement is fundamental, particularly in light of the deep changes that Italian governmental bodies are undergoing, with an entirely digital process and the recent modifications to the Codice dell'Amministrazione Digitale about free and open source software and use of public datasets.

The 2007 workshop is to date the only one organised by neither a university nor another public institution (IISL is a no-profit organisation, in the field of cultural heritage preservation, research and museums). Together with the 2008 meeting, this workshop has been the only one not organised by employed staff (in 2007 Gianluca Pesce was a freelance professional and Stefano Costa a 
master student at the University of Siena). Although this exceptional situation is no justification, it is useful to understand both the delay of this publication and the great freedom we enjoyed in making choices on our own.

During this workshop we had a long round table after the speakers' talks. The round table was focused on data sharing, as described above in more detail. We recorded a video of the round table, that we are going to make available to the public following the example of the 2009 workshop held in Rome. The video will be available through the archeofoss.org website.

IOSA continues its contribution towards ArcheoFOSS, organising seminars, editing the archeofoss.org website and promoting the workshop at the international level.

\section{Notes}

* Dipartimento di Archeologia e Storia delle Arti, Università degli Studi di Siena.

$\$$ Istituto per la Storia della Cultura Materiale.

** Istituto Internazionale di Studi Liguri, Genova.

${ }^{1}$ http://www.iosa.it/diritti/

${ }^{2}$ http://www.iosa.it/diritti/, in Italian. Cultural Heritage (patrimonio culturale) includes any archaeological activity and object under Italian law. 